of hydrochloric acid. The titration required about $5 \mathrm{~min}$. Selenious acid $\{(0.6 \sim 12) \mathrm{mg}\}$ was determined with a relative error and a coefficient of variation of less than $0.2 \%$. Metallic selenium reacts with concentrated nitric acid to produce selenious acid, which can be titrated similarly after decomposing the excess of nitric acid with urea. The whole procedure required $(10 \sim 15) \mathrm{min}$. Metallic selenium $\{(6 \sim 130) \mathrm{mg}\}$ was determined with a relative error of less than $0.3 \%$. The recommended procedures are as follows. (1) Determination of selenious acid: Place $10 \mathrm{ml}$ of $(5 \times$ $\left.10^{-4} \sim 10^{-2}\right) \mathrm{M}$ selenious acid into the titration cell. Add $20 \mathrm{ml}$ of $10 \mathrm{M}$ hydrochloric acid and dilute to $50 \mathrm{ml}$ with water. Titrate the resultant solution with $10^{-1} \mathrm{M}$ sodium thiosulfate standard solution amperometrically. (2) Determination of metallic selenium: Dissolve powdered selenium $\{(6 \sim 120) \mathrm{mg}\}$ with $(1 \sim 2)$ $\mathrm{ml}$ of concentrated nitric acid in a $20 \mathrm{ml}$ weighing bottle at $(90 \sim 100)^{\circ} \mathrm{C}$ using a water bath in $(4 \sim 6)$ min. Dilute the solution with water to make exactly $100 \mathrm{ml}$ of the sample solution. Place an aliquot of the sample solution into the titration cell. In the case of sampling weight of selenium less than $6 \mathrm{mg}$, use the whole dissloved solution for the determination. Titrate the resultant solution in the same manner as discribed in (1) after adding $(1 \sim 2) \mathrm{g}$ of urea.

(Received October 4, 1983)

\section{Keyword phrases}

determination of selenious acid and metallic selenium; amperometric titration; rotating platinum electrode; sodium thiosulfate.

\title{
フローインジェクション濁度分析法による 河川水中の塩化物イオンの定量
}

\author{
財津 剛久，前原 雅子，桐栄 恭二 ${ }^{\circledR *}$
}

(1983 年 9 月 28 日受理)

\begin{abstract}
硝酸銀と塩化物イオンとが 反応してできる 塩化銀の沈殿の濁度を測定して 塩化物イオンを定量する フローインジェクション分析法について検討した． 2 個のプランジャー型ボンプによりキャリャー液 $(0.2 \mathrm{M}$ 硝酸) と反応試薬液（硝酸銀，硝酸及びポリビニアルコール）を送液しキャリヤー液流中に試料 を注入する.キャリヤー液と反応試薬液は混合され，塭化物イオンと硝酸銀とが反応して生成した塩化 銀の沈殿がフローセル $(18 \mu \mathrm{l})$ を通過する際の濁度を測定する (測定波長 $440 \mathrm{~nm})$. 河川水中に存在す る主なイオンのうち $10^{-3} \mathrm{M}$ のケイ酸イオンと $10^{-3} \mathrm{M}$ の炭酸イオンはこの方法を妨害するが，弱酸 性陽イオン交換樹脂（Amberlite IRC-50, H 形）のカラムを流路系内（試料注入点と混合点の間）に 装着することによりこの妨害を除去できる．検量線は 0 ～14 ppm の範囲で直線性を示した．毎分 1.2 $\mathrm{ml}$ で送液し, 試料注入量 $500 \mu \mathrm{l}$, 反応コイル $1.0 \mathrm{~mm} \mathrm{i.} \mathrm{d.} \times 2 \mathrm{~m}$ としたとき分析速度は 1 時間当たり 15 試料である。
\end{abstract}

\section{1 緒 言}

河川水中にある塩化物イオンを測定する方法として， JIS K 0101，工業用水試験方法 (1979) で恃硝酸銀滴定 法を利用している.一方わが国に拈ける全国 225 河川 水の平均塩化物イオン濃度は $5.8 \mathrm{ppm}$ である1). 上記 の滴定法は, 煩雑な操作を要し, 又本邦河川水に適用し た場合にはその滴定值は低く, 正確な值を求めることは

* 岡山大学理学部 : 700 岡山県岡山市津島中 3-1-1
困難である.

塩化物イオンのフローインジェクション分析法 (FIA) として, 塩化物イオンがチオシアン酸水銀と反応してチ オシアン酸イオンを遊離し，鉄(III) イオンが存在する と鉄チオシアン酸錯体を形成し，その吸光度 $(480 \mathrm{~nm})$ を測定して塩化物イオン濃度を定量する方法がある2). しかしこの方法は水銀化合物を利用するため環境污染の おそれがある。

塩化物イオン電極を用いる FIA が発表されている3). 
しかしこの方法による塩化物イオンの測定可能な下限濃 度は $2 \mathrm{ppm}$ で, 検量線の直線性が得られる下限濃度は (4〜5) ppm である.

著者らは硝酸銀と塩化物イオンとが反応してでさる塩 化銀の沈殿の濁度を測定する FIA によって河川水中に ある 塩化物イオン 濃度を 精度良く定量することができ た. 本法は沈殿生成の濁度を測定するといらこと及び妨 害イオンの除去のために流路系に弱酸性陽イオン交換樹 脂カラムを装着したがそのための拡散とにより，キャリ 一オーバー（相互污染）が大きく, 測定回数が 1 時間当 たり 15 回と FIA としては幾分迅速さに欠けるが，JIS 法のように煩雑でなく又チオシアン酸水銀法のように水 銀化合物による 環境污染のおそれるない，定量範囲は 0 14 ppm であり日本の 河川水中の 塩化物イオンの平 均濃度が $5.8 \mathrm{ppm}$ であることからも本法は十分実用的 である。

$$
2 \text { 実験 }
$$

\section{$2 \cdot 1$ 装}

FIA 装置の流路系を Fig. 1 に示す. ボンブは協和精 密 KHU-W-52 型ダブルブランジャーマイクロポンプ を用い，両ボンプによる送液は $1.2 \mathrm{ml} / \mathrm{min}$ で行った。 吸光度の測定は島津 UV-140-02 型光電分光光度計を 使用し $18 \mu \mathrm{l} \quad(1.5 \mathrm{~mm}$ i. d. $\times 10 \mathrm{~mm})$ フローセルを用 いた. 恒温槽は小松ソリデート Coolnics Thermobath GTE-2 型を使用した.

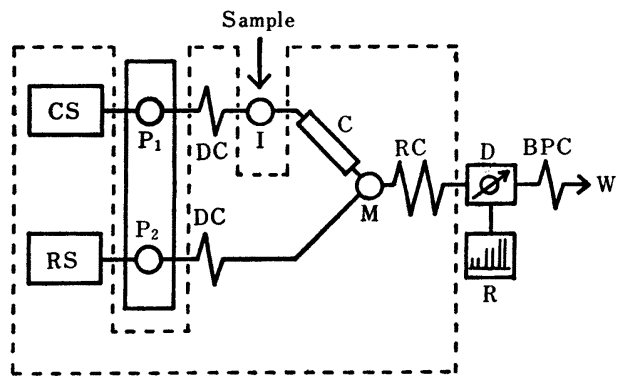

Fig. 1 Schematic diagram of flow system CS : Carrier solution; RS : Reagent solution; $P_{1}$ and $\mathrm{P}_{2}$ : Pump (flow rate $1.2 \mathrm{ml} / \mathrm{min}$ ); DC: Damper coil $(1.0 \mathrm{~mm}$ i. d. $\times 7 \mathrm{~m}) ; \quad$ I : Sample injection valve $(500$ $\mu \mathrm{l})$; $\quad$ C : Cation exchange resin column; $\mathbf{M}$ : Mixing joint; RC : Reaction coil $(1.0 \mathrm{~mm}$ i. d. $\times 2 \mathrm{~m})$; $\mathrm{D}$ : Spectrophotometer $(440 \mathrm{~nm}) ; \quad \mathrm{R}$ : Recorder; $\mathrm{BPC}$ : Back pressure coil $(0.25 \mathrm{~mm}$ i. d. $\times 1 \mathrm{~m})$; W : Waste ; Dotted line : Water bath $\left(25^{\circ} \mathrm{C}\right)$

\section{2 試 薬}

反応試薬液：諸条件を検討の結果, $10^{-2} \mathrm{M}$ 硝酸銀 500 $\mathrm{ml}, 1.6 \mathrm{M}$ 硝酸 $75 \mathrm{ml}, 1 \mathrm{~g} / \mathrm{l}$ ポリビニルアルコール (PVA)-217EE $25 \mathrm{ml}$ を混合して反応試薬液とした.
キャリヤー液 : $0.2 \mathrm{M}$ 硝酸

塩化物イオン標準液: $50^{\circ} \mathrm{C}$ で一昼夜減圧乾燥した特 級塩化ナトリウムを再蒸留水に溶かし $200 \mathrm{ppm}$ 液を調 製した．用途に応じ正確に希釈して用いた。

陽イオン交換樹脂カラム：Amberlite IRC-50 \{ H 形 (35〜45) mesh\} を再蒸留水でかき混せ，洗浄し内径 2.0 $\mathrm{mm}$, 長さ $30 \mathrm{~cm}$ のテフロンチューブに充てんして用い た。

\section{3 操 作}

試料をサンプルループ $(500 \mu \mathrm{l})$ に充てんし六方切り 換えバルブによりキャリャー液流中に注入する．注入さ れた試料は, 弱酸性陽イオン交換樹脂カラムを通過した 後反応試薬液流と $\mathrm{T}$ 字型ミキシングジョイントで混合さ れる. 混合された試料は, 反応コイルを通過して検出部 のフローセルに達する. そのときの濁度による吸光度の 変化を $440 \mathrm{~nm}$ で測定し記録する.

$$
3 \text { 結果 }
$$

\section{1 測定波曼}

本実験は生成した塩化銀の濁度を測定し塩化物イオン を定量するものである.ここではその測定波長の変化に よる吸光度の変化から測定波長を検討した.

測定波長 $(340 \sim 600) \mathrm{nm}$ で $10 \mathrm{ppm}$ 塩化物イオン標 準液のピーク高さを測定した結果を Fig. 2 に示す. 短 波長ではピーク高さが大きくなり高感度で測定できるが 再現性が悪く，長波長では再現性は良いが感度が低かっ た。

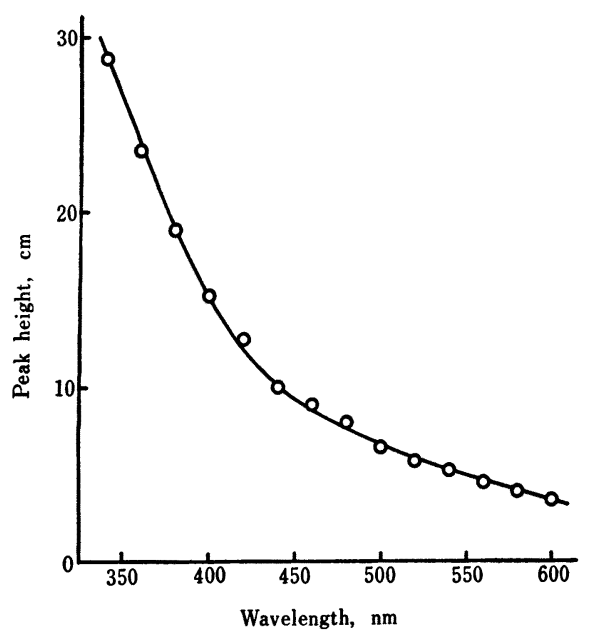

Fig. 2 Effect of wavelength on the peak height $\left(\sim 15^{\circ} \mathrm{C}\right)$

$\mathrm{Cl}^{-}: 10 \mathrm{ppm} ; \mathrm{RS}: 0.2 \mathrm{M} \mathrm{HNO}, 8 \times 10^{-3} \mathrm{M} \mathrm{AgNO}_{3}$, $0.04 \mathrm{~g} / \mathrm{l}$ PVA-217EE; CS : Water; Flow rate : $1.2 \mathrm{ml}$ / $\min$ 
日本の河川水中の 平均塩化物イオン濃度が $6 \mathrm{ppm}$ であ ることを考慮して測定範囲を $15 \mathrm{ppm}$ 以下としたので測 定波長として $440 \mathrm{~nm}$ を選んだ.

\section{2 硝酸銀壊度}

反応試薬液中の硝酸銀濃度の影響について調べた. 反 応試薬夜中の硝酸銀濃度 $(0.4 \sim 17) \times 10^{-3} \mathrm{M}$ で $5 \mathrm{ppm}$ 及び $10 \mathrm{ppm}$ の塩化物イオン標準液を注入しそのピーク 高さを測定した. 結果を Fig. 3 亿示す. 硝酸銀濃度が 低くなるほどピーク高さは大きくなるが $5 \mathrm{ppm}$ のピー ク高さと $10 \mathrm{ppm}$ のピーク高さの比が $1: 2$ とならず又 再現性も悪かった. 硝酸銀濃度 $5 \times 10^{-3} \mathrm{M}$ 以上でピー ク高さの比が $1: 2$ となり再現性も良かった. 本実験で は反応試薬液中の硝酸銀濃度を $8 \times 10^{-3} \mathrm{M}$ とした.

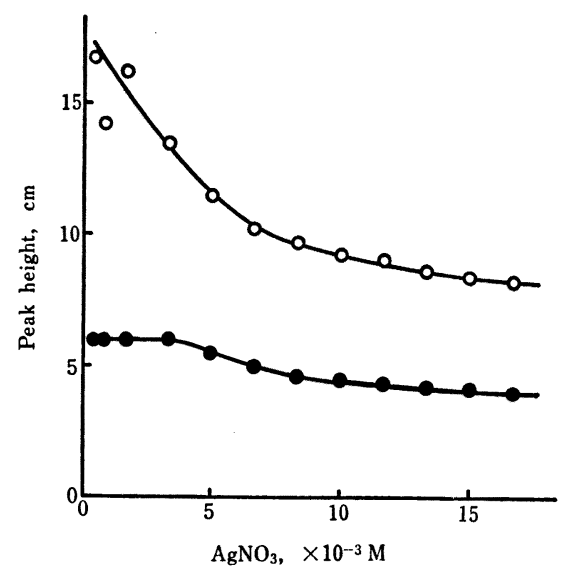

Fig. 3 Effect of silver nitrate concentration on the peak height $\left(\sim 15^{\circ} \mathrm{C}\right)$

$\mathrm{O}: 10 \mathrm{ppm} \mathrm{Cl}-; 0: 5 \mathrm{ppm} \mathrm{Cl}-; \mathrm{RS}: 0.2 \mathrm{M} \mathrm{HNO}_{3}$, $0.04 \mathrm{~g} / 1$ PVA-217EE; CS : Water; Flow rate : 1.2 $\mathrm{ml} / \mathrm{min}$; Wavelength : $440 \mathrm{~nm}$

\section{3 硝酸湞度}

反応試薬液中の硝酸濃度の影響について調べた. 反応 試薬液中の硝酸濃度 $0 \sim 0.4 \mathrm{M}$ で $6 \mathrm{ppm}$ 及び $10 \mathrm{ppm}$ の塩化物イオン標準液のピーク高さを測定した. 結果を Fig. 4 に示す. 硝酸濃度 $0.1 \mathrm{M}$ 以上でピーク高さが一 定となり, $6 \mathrm{ppm}$ と $10 \mathrm{ppm}$ のピーク高さの比も $3: 5$ となる. 又再現性す良かった. 本実験では, 反応試薬夜 中の硝酸濃度を $0.2 \mathrm{M}$ とした.

\section{4 保讙コロイド}

本法は塩化銀生成による濁度を測定し塩化物イオンを 定量するものであるから再現性良く定量するには，均一

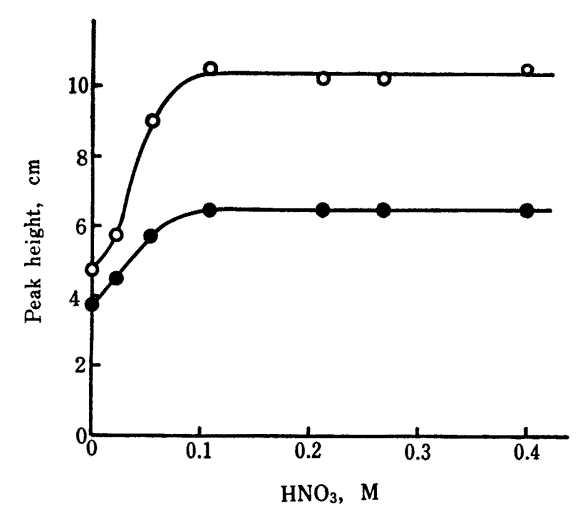

Fig. 4 Effect of nitric acid concentration on the peak height $\left(\sim 15^{\circ} \mathrm{C}\right)$

$\mathrm{O}: 10 \mathrm{ppm} \mathrm{Cl}-; \quad 0: 6 \mathrm{ppm} \mathrm{Cl}-; \quad \mathrm{RS}: 8 \times 10^{-3} \mathrm{M}$ $\mathrm{AgNO}_{3}, 0.04 \mathrm{~g} / 1$ PVA-217EE; CS : Water; Flow rate : $1.2 \mathrm{ml} / \mathrm{min}$; Wavelength : $440 \mathrm{~nm}$

な濁りが得られ又流路系への塩化銀の付着を防がねばな らない，そのために反応試薬液に加える保護コロイドと して PVA, PEO (ポリエチレンオキサイド), ゼラチ ンをそれぞれ試みた。 PEO は酸性域に打ける安定性が 悪く時間経過とともに粘度が低下し，ゼラチンはかなり の濁りをもち時間経過とともに銀イオンと反応した。本 害験では無色で安定性の良いPVA-217EE を保護コ口 イドとして加えることにした。

反応試薬夜 $115 \mathrm{ml}$ に対して 0 10 g/1 の PVA-217 EE $5 \mathrm{ml}$ を加えて $6 \mathrm{ppm}$ 及び $10 \mathrm{ppm}$ の塩化物イオン 標準液のピーク高さを測定した. 結果を Fig. 5 亿示す. PVA を加えない場合再現性が 非常に悪かった. 反応試

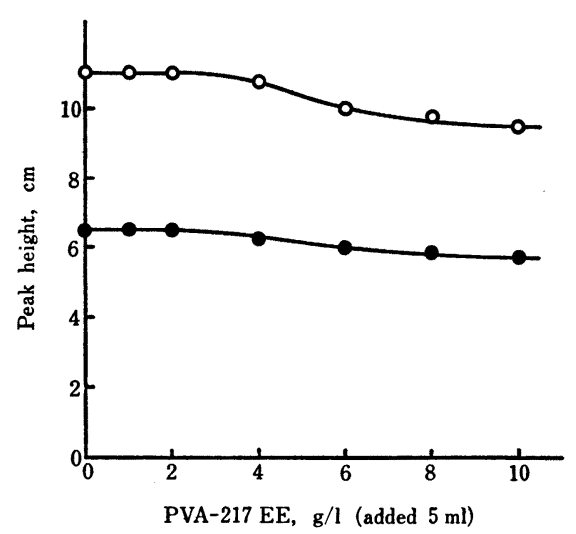

Fig. 5 Effect of polyvinyl alcohol concentration on the peak height $\left(\sim 15^{\circ} \mathrm{C}\right)$

$\mathrm{O}: 10 \mathrm{ppm} \mathrm{Cl}-; 0: 6 \mathrm{ppm} \mathrm{Cl}-; \mathrm{RS}: 0.2 \mathrm{M} \mathrm{HNO}_{3}$, $8 \times 10^{-3} \mathrm{M} \mathrm{AgNO}_{3}, 115 \mathrm{ml}$; CS : Water; Flow rate : $1.2 \mathrm{ml} / \mathrm{min}$; Wavelength : $440 \mathrm{~nm}$ 
薬液に加兄る PVA 溶液の濃度が $2 \mathrm{~g} / 1$ まではピーク高 さは一定であり再現性も良かった. 又 PVA 濃度が $2 \mathrm{~g} /$ 1 以上になるとピーク高さが減少する.この結果より本 実験では反応試薬液 $115 \mathrm{ml}$ に対して $1 \mathrm{~g} / 1 \mathrm{PVA}-217 \mathrm{EE}$ $5 \mathrm{ml}$ を加えて反応試薬液とした.

\section{5 共存イオン}

河川水中の塩化物イオンを定量するに当たり河川水中 に存在する主なイオンについてその影響を調べた. 結果 を Table 1 に示す.

Table 1 Effect of co-existing ions on determination of chloride

\begin{tabular}{|c|c|c|c|c|}
\hline Ion & Added as & $\begin{array}{c}\text { Average } \\
\text { value in } \\
\text { Japan }^{11} \\
\text { (M) }\end{array}$ & $\begin{array}{l}\text { Concen- } \\
\text { tration } \\
\text { (M) }\end{array}$ & $\underset{(\%)}{\text { Recovery }}$ \\
\hline $\mathrm{Ca}^{2+}$ & $\mathrm{Ca}\left(\mathrm{NO}_{3}\right)_{2}$ & $2.1 \times 10^{-4}$ & $10^{-2}$ & 102 \\
\hline $\mathrm{Mg}^{2+}$ & $\mathrm{MgSO}_{4}$ & $7.8 \times 10^{-5}$ & $10^{-3}$ & 100 \\
\hline $\mathrm{Na}^{+}$ & $\mathrm{Na}_{2} \mathrm{SO}_{4}$ & $2.9 \times 10^{-4}$ & $10^{-2}$ & 101 \\
\hline $\mathrm{K}^{+}$ & $\mathrm{KNO}_{3}$ & $3.0 \times 10^{-5}$ & $10^{-2}$ & 99 \\
\hline $\mathrm{HCO}_{3}^{-}$ & $\mathrm{NaHCO}_{3}$ & $5.1 \times 10^{-4}$ & $10^{-3}$ & 92 \\
\hline $\mathrm{SO}_{4}{ }^{2-}$ & $\mathrm{Na}_{2} \mathrm{SO}_{4}$ & $1.1 \times 10^{-4}$ & $10^{-2}$ & 101 \\
\hline $\mathrm{SiO}_{3}{ }^{2-}$ & $\mathrm{Na}_{2} \mathrm{SiO}_{3}$ & $3.2 \times 10^{-4}$ & $10^{-3}$ & 35 \\
\hline $\mathrm{Fe}^{3+}$ & $\mathrm{Fe}_{2}\left(\mathrm{SO}_{4}\right)_{3}\left(\mathrm{NH}_{4}\right)_{2} \mathrm{SO}_{4}$ & $4.3 \times 10^{-6}$ & $10^{-4}$ & 100 \\
\hline $\mathrm{H}_{2} \mathrm{PO}_{4}^{-}$ & $\mathrm{NaH}_{2} \mathrm{PO}_{4}$ & $2.1 \times 10^{-7}$ & $10^{-4}$ & 97 \\
\hline $\mathrm{NO}_{3}^{-}$ & $\mathrm{Ca}\left(\mathrm{NO}_{3}\right)_{2}$ & $1.9 \times 10^{-5}$ & $10^{-2}$ & 102 \\
\hline $\mathrm{NH}_{4}{ }^{+}$ & $\left(\mathrm{NH}_{4}\right)_{2} \mathrm{SO}_{4}$ & $3.6 \times 10^{-6}$ & $10^{-2}$ & 99 \\
\hline
\end{tabular}

$\dagger \mathrm{Cl}$ added : $10 \mathrm{ppm}$

共存するイオンのらちで炭酸イオン及びヶイ酸イオン は, 本法を妨害する. 本実験ではH形弱酸性陽イオン交 換樹脂を充てんしたカラムを流路系内に装着し, 更にキ ヤリヤー液を $0.2 \mathrm{M}$ 硝酸溶液とすることによりこの妨 害を除去した。すなわち試料溶液とともに注入された 炭酸水素ナトリウム及びヶイ酸ナトリウムはアルカリ 性であるため, H形弱酸性陽イオン交換樹脂を通すこと により中和されるとともに, $0.2 \mathrm{M}$ 硝酸溶液によりイオ ン交換樹脂は再びH形に再生される. 従って数か月使用 してもイオン交換樹脂の 機能の 低下は認められなかっ た. $10 \mathrm{ppm}$ の塩化物イオンを注入してその回収率を求 めた結果は, 炭酸イオンが共存する場合が $101 \%$ ケイ 酸イオンが共存する場合が $98 \%$ であった.

\section{6 温度の影響と検量線}

本法は塩化銀の沈殿生成による濁度を測定して塩化物 イオンを定量するものであるから測定する際の温度の影 響が非常に大きい。温度の影響により，生成する塩化銀 の濁度の均一性が左右され精度, 再現性が非常に悪くな る. そこで恒温槽で流路系, 反応試薬液, キャリャー
液, 注入試料の温度を一定とした. $15^{\circ} \mathrm{C}, 20^{\circ} \mathrm{C}, 25^{\circ} \mathrm{C}$ それぞれの温度で定量操作に従い検量線を作成した. 25 ${ }^{\circ} \mathrm{C}$ に打ける検量線用のシグナルを Fig. 6 に示す.

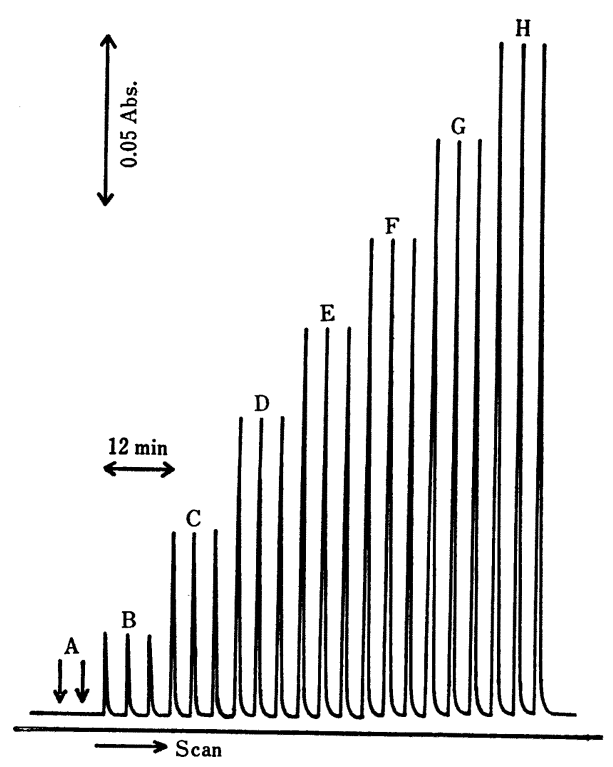

Fig. 6 Flow signals at $25^{\circ} \mathrm{C}$ $\mathrm{Cl}^{-}(\mathrm{ppm}): \mathrm{A}$ 0; $\quad$ B $2.0 ; \quad$ C $4.0 ; \quad$ D $6.0 ;$ E 8.0 ; F $10.0 ;$ G $12.0 ;$ H 14.0

Table 2 Determination of chloride in river and city waters

\begin{tabular}{|c|c|c|c|c|c|c|}
\hline \multirow{3}{*}{ Sample† } & & \multicolumn{3}{|c|}{$\mathrm{Cl}^{-}$(ppm) } & \multirow{3}{*}{$\begin{array}{c}\text { Re- } \\
\text { covery } \\
(\%)\end{array}$} & \multirow{3}{*}{$\underset{\text { samplet† }}{\mathrm{Cl}^{-} \text {in }}$} \\
\hline & & \multicolumn{2}{|c|}{ Found } & \multirow{2}{*}{$\begin{array}{c}\mathrm{Re}- \\
\text { covered }\end{array}$} & & \\
\hline & & None & $\begin{array}{l}\text { Added } \\
8 \mathrm{ppm}\end{array}$ & & & \\
\hline \multirow[t]{5}{*}{ Asahi river } & 1 & 1.4 & 9.5 & 8.1 & 101 & 2.3 \\
\hline & 2 & 1.9 & 10.1 & 8.2 & 103 & 3.1 \\
\hline & 3 & 1.9 & 9.9 & 8.0 & 100 & 3.1 \\
\hline & 4 & - & - & - & - & 5.8 \\
\hline & 5 & - & - & - & - & 6.1 \\
\hline \multirow[t]{3}{*}{ Yoshii river } & 1 & 1.3 & 9.1 & 7.8 & 98 & 2.1 \\
\hline & 2 & 1.8 & 9.4 & 7.6 & 95 & 2.9 \\
\hline & 3 & 1.6 & 9.4 & 7.8 & 97 & 2.8 \\
\hline \multirow[t]{6}{*}{ Takahashi river } & 1 & 1.5 & 9.4 & 7.9 & 99 & 2.3 \\
\hline & 2 & 1.2 & 9.4 & 8.2 & 102 & 2.1 \\
\hline & 3 & 1.2 & 9.0 & 7.8 & 97 & 2.1 \\
\hline & 4 & - & - & - & - & 5.8 \\
\hline & 5 & - & - & - & - & 5.1 \\
\hline & 6 & - & - & - & 一 & 4.7 \\
\hline City water & & 4.5 & 12.7 & 8.2 & 103 & 7.5 \\
\hline
\end{tabular}

$\dagger$ Sample taken : 1, 2, and 3 on July 29th 1983 (after rain), 4, 5, and 6 on July 22nd 1982. It Sample solution was prepared by addition of $15 \mathrm{ml}$ of sample and $8 \mathrm{ppm}$ of chloride ion to $25 \mathrm{ml}$ of volumetric flask, and $\mathrm{Cl}^{-}$in sample is average of three measured values. 
それぞれの温度で 検量線は 0 〜 $10 \mathrm{ppm}$ の範囲で良い 直線性を示すが，温度の検量線に及ぼす影響は大きく， 温度が高いほうが検量線の傾きが大きい. 又 $25^{\circ} \mathrm{C}$ で は定量範囲が $0 \sim 14 \mathrm{ppm}$ となり，この温度が室内温度 とほぼ同じであったので本実験では系の温度を $25^{\circ} \mathrm{C}$ とした. 又温度を一定とすることにより再現性が非常に 良くなった。

\section{7 実試料の分析}

岡山県下の三大河川である旭川, 吉井川, 高梁川及び 水道水について塩化物イオンの定量を行った. 結果を Table 2 に示す.

終わりに, 本研究費の一部は財団法人日産科学研究振 興財団・学術研究助成金によった. 又ポリビニルアルコ ールは(株)クラレから寄贈をうけた。ここに感謝の意を 表する.

\section{文献}

1) 小林 純 : 農学研究, 48, 91 (1960).

2) J. Růžička, E. H. Hansen : "Flow Injection Analysis", p. 156 (1981), (John Wiley \& Sons, New York).

3) 古谷 博, 中山敬三郎 : 水道協会雑誌, 52, 51 (1983).
Flow injection analysis by using turbidimetry for chloride in river water. Takahisa ZAITSU, Masako MaEhara, and Kyoji Tôei (Department of Chemistry, Faculty of Science, Okayama University, 3-1-1 Tsushima-naka, Okayama-shi, Okayama, 700)

Carrier solution(0.2 M nitric acid) and reagent solution $\left(500 \mathrm{ml}\right.$ of $10^{-2} \mathrm{M}$ silver nitrate, $75 \mathrm{ml}$ of $1.6 \mathrm{M}$ nitric acid, and $25 \mathrm{ml}$ of $1 \mathrm{~g} / \mathrm{l}$ polyvinyl alcohol) were propelled by double plunger pump(flow rate $1.2 \mathrm{ml} /$ min), and sample solution $(500 \mu \mathrm{l})$ was injected into the carrier stream. The two streams were mixed in $2 \mathrm{~m}$ Teflon tubing $(1.0 \mathrm{~mm}$ i.d.) and the turbidity in stream was measured through a flow cell $(18 \mu \mathrm{l})$ at $440 \mathrm{~nm}$. Among ordinary co-existing ions in river water, $10^{-3} \mathrm{M}$ silicate ion and $10^{-3} \mathrm{M}$ carbonate ion interfered with the determination of chloride. This interference could be eliminated by fitting ion-exchanger (Amberlite IRC-50, $\mathrm{H}$ type) column into a carrier line and running a stream through it. The linear relationship between the peak height and concentration of chloride was obtained at the range of 0 to 14 ppm. The sampling rate was 15 samples per hour.

(Received September 28, 1983)

\section{Keyword phrases}

turbidimetric determination of chloride by flow injection analysis; river and city waters samples; flow injection analysis of natural waters for chloride. $\stackrel{s}{s}$

\title{
熱分解ガスクロマトグラフィーによる多成分系
}

\section{アクリル酸エステル共重合体の組成分析}

\author{
山口 茂彦，横山 伸一®* \\ (1983 年 10 月 28 日受理)
}

\begin{abstract}
多成分のアクリル酸エステル,メタクリル酸エステルを構成単位として含む共重合体の組成をパイロ グラムのビーク面積比より簡便に求める分析法について検討した．共重合体の熱分解によって生成する アクリル酸エステル/メタクリル酸エステルのモノマー量の比は両者の組成比によって変化するため, モノマー量の比から組成比を求めるためには補正が必要である.この補正係数の決定にアクリル酸エス テルのモノマー/ダイマー量の比を用いることを考えた． 検討の結果，熱分解によって生成するアクリ ル酸エステルのモノマー/ダイマー量の比は, 組成既知の試料について求められた補正係数と一義的に対 応することが分かった，從って，多成分系共重合体においてもパイログラムから組成比の決定が可能で ある. 本法を用いて, アクリル酸エチル(EA)ーメタクリル酸エチル (EMA)ーメタクリル酸ブチル (BMA) 共重合体，及び EA-アクリル酸ブチル（BA）-EMA 共重合体の組成を分析したところ，良好な結果が 得られた.
\end{abstract}

*日本油脂 (株)筑波研究所 : 244 神奈川県横浜市戸塚区下倉田町 296 